\title{
Vlog as Learning Instrument in Introduction to International Relations to Improve Student Learning Outcomes
}

\author{
Anita Afriani Sinulingga ${ }^{1}$, Putiviola Elian Nasir ${ }^{2}$, Sofia Trisni ${ }^{3}$ \\ $\left\{\right.$ nanisinulingga@gmail.com ${ }^{1}$ \} \\ ${ }^{1,2,3}$ Department of International Relations, Faculty of Social and Political Science, Universitas \\ Andalas, Padang, Indonesia
}

\begin{abstract}
The purpose of writing this article is to describe the improvement in student learning outcomes after using vlog (video blogging) as a learning instrument in the Introduction to International Relations Course. The study of International Relations is often considered as a study separate from the society's daily lives in developing countries. Vlog is used as a means to ground the study of International Relations in Indonesia, especially in West Sumatra and Padang. This type of research is based on classroom action using the 4D (Four D) development model learning device. This study was designed with four stages of development, which are defining, planning, developing and distributing. This subject of this research was the second semester students (year 2018) with a total of 87 people. Data collection is conducted through the method of observation. The results described that the learning process using vlog can stimulate the active participation of students in th Al Maghvirah Chane-learning process and develop a more enjoyable classroom atmosphere. Through the application of performance assessment methods, there was an increase in the percentage of student learning outcomes in the Introduction to International Relations Course.
\end{abstract}

Keywords: Video blogging, learning outcomes, Introduction to International Relations

\section{Introduction}

Introduction to International Relations (PIHI) is a mandatory course offered to students in the second semester. PIHI courses have an important position in the curriculum of International Relations (HI), which is the paradigm, the foundation for understanding the phenomenon of international relations. In line with its placement in the curriculum in the second semester, it is intended to lay the framework to understand the phenomenon of international relations. This course aims to prepare students to observe and analyze the international phenomenon from the paradigm of international relations. In the short term, this course aims to guide students to determine the scope of the study of international relations and its difference with other social and political science studies.

Introduction to International Relations is one of the core subjects of the International Relations (IR) Department's curriculum structure besides International Relations Theory I and II as well as the International Relations Research Methodology I and II. Before enrolling in PIHI, students have studied Introduction to Political Science in the first semester which becomes the theoretical knowledge base in the social and political sciences. In the early semester it is important to lay the foundation for ontological, epistemological, and axiological thinking. Therefore, the PIHI course provides a framework for students, enabling them to study 
international phenomena from the paradigm of International Relations. The position of PIHI course in the curriculum structure of the IR Department can be seen in Figure 1.

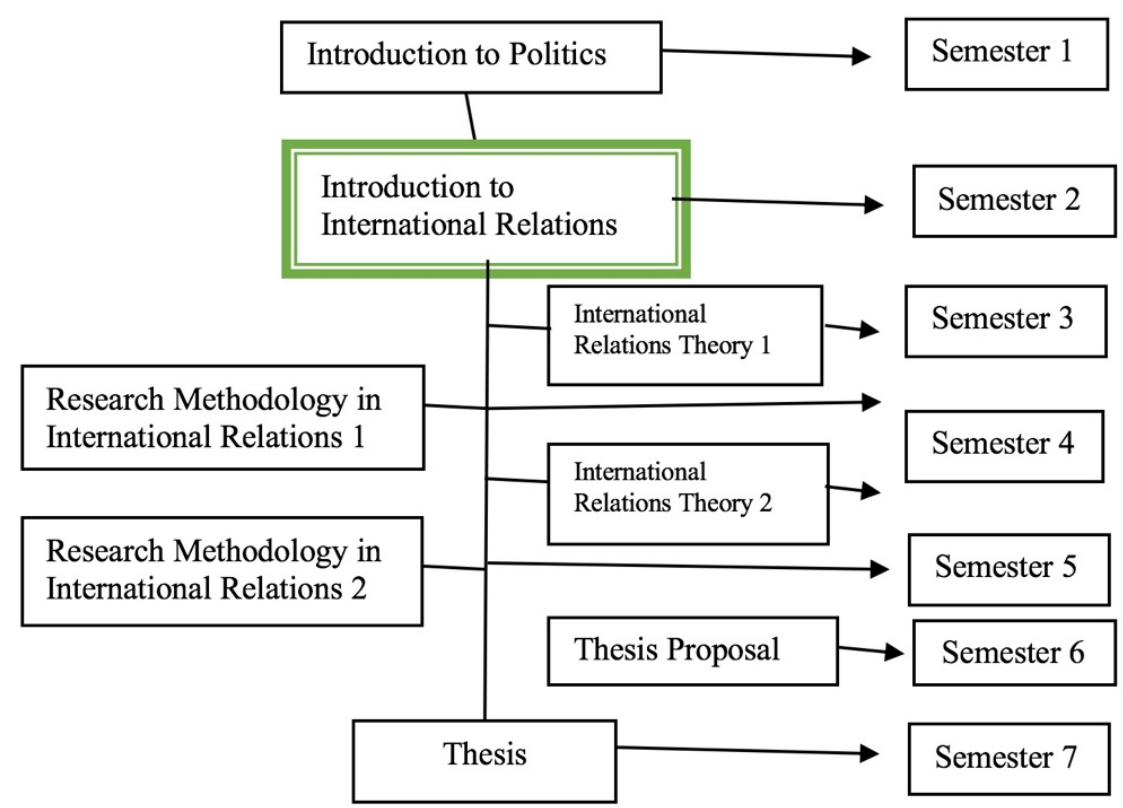

Figure 1. Scheme of Core Subjects / Core Subject Department of Relationship

In general, lectures apply the SCL (Student-Centered Learning) learning method by combining lectures by the instructor, small group discussions, assignments, and presentations. Within the learning process, learning material is delivered through lecture handouts supplemented with teaching material in the form of powerpoints. All lecture material, assignments, and the assessment of these assignments are collected through Andalas University's i-learn: hi.fisip.unand.ac.id. The learning outcomes evaluation is adjusted to the learning method and classified into formative and summative evaluation. Formative evaluations are given through individual and group assignments with an assessment weight of $25 \%$ each. Whereas summative evaluations are conducted through midterm and final exams with the same value as summative tests. Previously the course syllabus was presented and discussed with students at the beginning of the lecture. This becomes important to prepare for the learning process in class.

However, in reality, although the SCL method has been applied in learning, there are still some problems in the learning process of this course. First, some students tend to be passive listeners, whereas some others are very active and responsive. Specifically for these passive students, lecturers struggle in ensuring their understanding of the lecture material delivered. Second, the desire to discover new knowledge and insights is still low. Students only depend on lecture material provided by lecturers in the classroom. There is a tendency of laziness towards reading, which can be seen from sources cited in lecture assignments, using more online news media. 
In addition, the results of student evaluations have not been satisfactory. This can be seen through the distribution of the course's final grade for students year 2017 / 2018 where the range of student grades is quite varied, from grades A to E, the majority of student grades had B + and A- by $17 \%$ and $14 \%$, while students who received A were only $11 \%$. Distribution of the final grades in the Introduction to International Relations can be seen in the following figure.

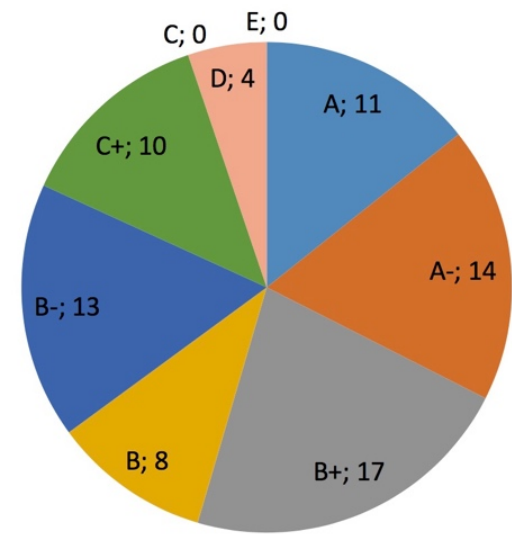

Figure 2. Distribution of Course Introductory Values for International Relations TA.2016 / 2017

Learning from these problems, it is necessary to look for strategies to improve the quality of learning through student and lecturer performance. It is important to introduce alternative solutions for actions taken to solve practical problems of learning in the classroom, then to improve and develop them.

\section{Intermestic Studies in International Relations and Student Learning Styles}

Other than completing a self-evaluation of the PIHI learning process in the 2017/2018 academic year, at the beginning of the lecture, the students of year 2018 who were taking PIHI lectures in the 2018/2019 academic year, were interviewed regarding their reasons and initial knowledge related to the scope of international relations. A common understanding for students, especially for new students in the Department of International Relations, IR is the study of global events or events that occur in countries outside the boundaries of Indonesian jurisdiction and the effects or benefits of these events do not have consequences for the people of Indonesia. International events are understood to only affect government policies at the national level, not touching the daily lives of people and. In addition, IR is considered as consumption for people in developed countries, unlike how unimportant it is for people in developing countries like Indonesia. In other words, the study of international relations is considered a study that is far from everyday life.

The above understanding is incorrect. Using Putnam's thought of the logic of two-level games which explains that conditions occurring at the domestic level are influenced by international conditions, it should also be the case that domestic conditions that occur within the jurisdiction of a country can also have a significant influence on international conditions or global trends. Therefore it is important to "ground" the study of IR.

The strategy to connect IR to everyday life can be explained by an intermestic approach. Intermestic is a combination of words from international and domestic. This approach is a relatively new approach that believes that the international system influences domestic phenomena which consist of issues, policies, or norms/ideas. The phenomenon of globalization 
which encourages economic, political, and cultural integration generates to intermesticity between the international and domestic systems, for example through trade, capital, and human flows across national borders. The role of intermestic studies is to bring IR knowledge which has so far only been understood as the issue of foreign politics, diplomacy, and studies of other countries, to be closer to everyday human life. Through this approach, IR scholars, including students, could notice and attend more issues, policies, and ideas/norms in the country by keeping in touch with what is happening internationally. Likewise, domestic political researchers are expected to broaden their perspective by not only looking at domestic matter alone.

To improve the quality of learning, it is important to understand instructional media that are in accordance with the characteristics of existing generations in higher education. Currently, there are several generations with their respective characteristics. In general, leaders (head of...) and lecturers in higher education are the Baby Boomers generation, generation $\mathrm{X}$ and part generation $\mathrm{Y}$, semester students or university students consist of part of generation $\mathrm{Y}$ and in general generation $\mathrm{Z}$. Some of the existing generations in higher education can be seen in Table 1 .

\begin{tabular}{llllll}
\hline \multicolumn{1}{c}{ Description } & \multicolumn{1}{c}{$\begin{array}{c}\text { Baby } \\
\text { Boomers }\end{array}$} & Generasi X & Generasi Y & Generasi Z & $\begin{array}{c}\text { Generasi } \\
\text { Alpha }\end{array}$ \\
\hline Year of birth & $1946-1964$ & $1965-1979$ & $1980-1995$ & $1996-2010$ & $2011-2025$ \\
Status & Head of... & / & Head of... / & Lecturer \\
& Lecturer & $\begin{array}{l}\text { Lecturer PPs } \\
\text { Student }\end{array}$ & & Undergraduate & Student \\
& & & Student & \\
\hline
\end{tabular}

Table 1. Generations timeline of by year of birth and status in university

Seeing that the majority of undergraduate study program students today are Generation $Z$, it is very important to understand the characteristics of the generation in considering the learning technology that will be applied in lectures. Characteristics of Generation $\mathrm{Z}$ include ${ }^{1}$ :

1. Fluent in Technology: tech-savvy, web-savvy, appfriendly generation

2. Social: intensely interacting through social media with all groups

3. Expressive: tend to be tolerant of cultural differences and very concerned with the environment

4. Moving rapidly from one thought to another / one job to another thought / another job (fast switcher)

Related to the learning method, it is important to adapt it to the characteristics of the $\mathrm{Z}$ generation; whom are the students attending lectures. Chun. et al explained that universal learning strategies can still be used but adjustments are needed in certain parts by developing technological devices. Furthermore, Chun et al explain the characteristics of learning in accordance with Generation Z, among others ${ }^{2}$ :

1. Fast delivery, convey in visual form (data and graphics or if necessary with video),

2. Kinesthetic, experimental, problem solving, direct activities,

1 Wibawanto, Hari. Generasi $\mathrm{Z}$ dan Pembelajaran di Pendidikan Tinggi. Bandung: UPT elearning ITB diakses dari

1. https://event.elearning.itb.ac.id/assets/download/materi3.pdf(19 Februari 2019)

${ }^{2}$ Chun, Christine dkk. 2017. Teaching Generation $Z$ at the University of Hawaii, Hawaii: The IAFOR International Conference on Education 
3. Search for information that is fast, convenient, and has short-cuts (students can access from anywhere, anytime),

4. Integrate multimedia (use social media),

5. Multiple tasks (multitasking),

6. Fast feedback, clear, challenging goals, prizes, and positives,

7. Submission of short material accompanied by pauses,

8. Trial approach,

9. The task must be in the form of problem-solving and not remembering (memorization),

10. In the form of group work,

11. Flexibility to master teaching materials according to the best for students.

By understanding these characteristics, the vlog is then considered as an interesting learning instrument. This vlog media enables students to be actively involved in making vlogs, stimulates students to think creatively and at the end of the project, students are able to create a more enjoyable learning process. Furthermore, these vlogs use multimedia devices, specifically electronic devices such as cell phones/cellphones and also social media which are information and communication instruments that are owned by almost all students which they access throughout the day. This means that familiarity of students towards multimedia-based technological devices enable a high probability of successful vlog development.

\section{Research Procedure}

Strategy to improve student learning outcomes apply the 4D (Four D) development model learning device, created by Thiagarajan et al. In the initial stages, it is important to explain the learning objectives achieved in the Introduction to International Relations course that is tailored to the characteristics of the students taking the course. In the next section, based on the objectives and evaluation of learning, video blogging (vlog) as a learning instrument is developed. In the final section, a learning evaluation method is developed through performance assessment as an alternative form of assessment. The level of success criteria for action in this study is seen from the ability of students to understand intermestic issues in IR studies, which will increase in each cycle and shows the level of achievement of learning success with a grade of $\geq 75$ with a minimum amount of $60 \%$ of the student population. If indicators of success on student understanding and skills have been reached, the study is stopped.

The Introduction to International Relations course is a team teaching class. The division of tasks between lecturers includes three main activities which are planning, implementation, evaluation, and reflection stages. At the planning stage, a team of lecturers prepares a syllabus (RPS). After discussing the RPS within the team, the RPS was discussed again in the RPS review in the faculty lecturer forum. Through the forum, other fellow lecturers will provide input and consideration which are useful to strengthen the learning plan.

At the implementation stage, the lecturer will deliver lecture materials in turn. In the classroom, other fellow lecturers will help prepare the implementation of the SCL method and help assess students' performance during the learning process. Assessment is conducted by evaluating the process and results using the assessment instruments that have been prepared previously. Assessment is not only at the end of the semester but is conducted at each meeting through assignments.

Then, the teaching team will discuss the result of students' learning experiences that reflect the lecture performance of learning. Students' learning experiences will be used as lecturer's 
feedback to improve and increase the lecture performance in the learning process, learning stregeis, and student assessment method. In detail, the steps of $4 \mathrm{~d}$ research implementation is explained in Table 2. At the end of the semester, the lecturer is able to recapitulate student performance. One lecturer, will upload grades into the university's academic portal. In order for student grades to be accountable and transparent, lecturers will submit assessment recapitulation to students and return their learning documents including assignments, quizzes, class projects, answer sheets, and others. Furthermore, the lecturer team will conduct a student learning outcomes discussion which is a reflection of the lecturers' performance in learning. Student learning outcomes are feedback for lecturers in improving the lecturer's performance in the learning process, towards learning strategies, and evaluating student learning. In more detail, the stages of $4 \mathrm{D}$ are explained in Table 2.

Table 2. Stages of 4D Research Implementation

\begin{tabular}{|c|c|}
\hline Tahapan & Pelaksanaan \\
\hline Defining & $\begin{array}{l}\text { 1. The lecturer conducts a self-evaluation of the previous learning process } \\
\text { 2. The lecturer analyzes the general characteristics of students } \\
\text { 3. Lecturers design lecture assignments } \\
\text { 4. The lecturer identifies the main concepts that will be conveyed in the } \\
\text { lecture assignment } \\
\text { 5. The lecturer determines the learning objectives }\end{array}$ \\
\hline Planning & $\begin{array}{l}\text { 1. The lecturer identifies and chooses learning instrument that is suitable } \\
\text { with the student's character, namely vlog media } \\
\text { 2. The lecturer divides students into groups and learning topics raised in } \\
\text { assignments } \\
\text { 3. The instructor instructs students to develop a lecture assignment design } \\
\text { 4. Lecturers provide input and suggestions on the design of student } \\
\text { assignments } \\
\text { 5. The lecturer prepares an assessment rubric }\end{array}$ \\
\hline Developping & $\begin{array}{l}\text { 1. The lecturer instructs students to develop the initial design of lecture } \\
\text { assignments } \\
\text { 2. Lecturers provide advice and input on the final draft lecture design } \\
\text { 3. Students compile story boards from vlogs } \\
\text { 4. Students go to the field to make a vlog } \\
\text { 5. The lecturer socializes the assessment instrument to students }\end{array}$ \\
\hline Distributing & $\begin{array}{l}\text { 1. Students present a vlog that has been prepared in the } 2019 \text { PIHI Class } \\
\text { Seminar } \\
\text { 2. Lecturers provide assessments and feedback on vlogs prepared by } \\
\text { students. } \\
\text { 3. The lecturer prepares a new RPS based on the activities that have been } \\
\text { carried out }\end{array}$ \\
\hline
\end{tabular}

The selection of student learning outcomes assessment in this study departs from the expected results of learning in terms of cognitive, affective, and psychomotor aspects. This type of performance assessment is an effort to improve and complement the traditional assessment (test and non-test assessment) to include the process in the assessment of learning outcomes. On the other hand, Bloom (1956) reminded that the choice of assessment must be adjusted to the learning objectives by clearly identifying cognitive, affective, and psychomotor learning outcomes. The basis of performance assessment is that lecturers give assignments, students 
respond through showing their abilities, and assessments based on certain indicators with instruments called rubrics. There are three types of rubric which are descriptive rubric, holistic rubric, and perception scale rubric. In this study, one of the three rubrics will be developed, which is a holistic rubric because the format of the arrangement is simpler when compared to other rubric types.

Vlog project assessment includes four main elements, namely media, cognitive, affective, and psychomotor, each element has a maximum value of 25 points. Based on the results of data collection, researchers analyzed the data in a format that was prepared previously:

a. The elements in the instrument related to the quality and creativity of students in preparing vlogs as audiovisual media.

b. Elements in cognitive aspects related to the ability of students to understand the scope of International Relations, the international aspects of events and events that occur around us, and students' knowledge of the basic concepts in International Relations.

c. Elements in affective aspects related to self-confidence, the ability to accept, respond to, and appreciate the opinions/suggestions / criticisms/questions of others, and the ability to work in teams.

d. Elements in psychomotor aspects related to systematics and coherence between topics, concepts and audiovisual as well as spontaneity in answering/responding to class participants' questions

\section{Results and Discussion}

\section{Student Learning Outcomes}

This research was conducted during the learning process in the Introduction to International Relations course which was conducted in the semester of 2018/2019. The duration of the learning process was 16 weeks by applying student-centered learning methods / SCL through making video blogging (vlog). This method provides students with the opportunity to discover knowledge and conduct the learning process outside the classroom. It started by dividing students into 14 small groups, each group consisting of 5-6 students. The division of groups is based on 7 lecture topics determined by the supporting lecturer. On each learning topic, there are two groups that have the same topic and presentation schedule. Group projects are presented each week in sequence in accordance with the order of the learning topics listed in the syllabus. Topics presented by students included foreign policy, diplomacy, international security, international organizations/regimes, global political economy, international human rights/humanitarianism, and international development.

Assessment in this course was conducted during the learning process through group project presentation activities and class discussions. The assessment is also done at the end of the learning process; through the Midterm and Final Exams. At the end of the learning process, the students apply the vlog method to evaluate their ability in grounding the study of International Relations, especially in linking issues/trends, actors, or global values with events and conditions that occur at the domestic level. Furthermore, the aim of this research was the actualization of the intermestic approach in the study of International Relations.

The results demonstrated that the grade distribution of International Relations students in the PIHI course which applied the method of video blogging (vlog) was better than the distribution of student scores in PIHI courses that did not apply the method in the previous academic year. The following is a comparison table of student learning outcomes in the Introduction to International Relations in the 2017/2018 and 2018/2019 academic years: 


\begin{tabular}{lllc}
\hline \multirow{2}{*}{ No } & Grade & \multicolumn{2}{c}{ Grade Distribution } \\
\cline { 3 - 4 } & & $11(14,28)$ & year 2018/ 2019 \\
\hline 1 & A & $14(18,18)$ & $22(25,28)$ \\
2 & A- & $17(22,07)$ & $32(36,78)$ \\
3 & B + & $8(10,38)$ & $12(13,79)$ \\
4 & B & $13(16,88)$ & $10(11,49)$ \\
5 & B- & $10(12,98)$ & $2(2,29)$ \\
6 & C + & $0(0)$ & $1(1,14)$ \\
7 & C & $4(5,19)$ & $4(4,59)$ \\
8 & D & $0(0 \%)$ & $1(1,14)$ \\
9 & E & 77 & $3(3,44 \%)$ \\
& Student Total & & 87 \\
\hline
\end{tabular}

Table 3. Comparison of Student Learning Outcomes

The data in the table above shows that the distribution of the final grades of students in the PIHI course in the current semester showed an increase in grades A and A- obtained by as many as $62.06 \%$ of students, while in the previous academic year students who were able to achieve the highest grades of A and A $-32.46 \%$. For the lowest scores obtained by students in the academic year 2018/2019 in this course, the D and E grades which were $4,58 \%$, and $5,19 \%$ in the previous academic year. The students who received $\mathrm{D}$ was because they did not meeting the requirements to pass the course. The increase in the distribution of final grades of students in PIHI courses with the vlog development method compared to those subjects who applied the debate method in the previous year, shows that the vlog development method is quite effectively applied to the learning process.

\section{Student Responses to Vlog Development}

Based on the learning objectives and the assessment methods applied in this course, it can be concluded that the learning method through making vlogs is effective in fulfilling the assessment elements comprehensively. The students' grades targeted by implementing this learning and assessment method was a minimum of 75. In general, the average grade of each aspect is in the range of $70-77 \%$ or in the good category. Assessment of student learning outcomes covering all four aspects can be seen in Table 4 .

\begin{tabular}{lllll}
\hline & Media (25) & Cognitive (25) & Affective (25) & Psychomotor (25) \\
\hline Average Points & 19,4 & 19,0 & 17,7 & 17,8 \\
Average Grade (in\%) & 77,6 & 76 & 70,8 & 71,2 \\
\hline
\end{tabular}

Table 4. Four Aspects of Assessing Student Learning Outcomes

The table above demonstrates assessment towards students' abilities in media elements is quite high, in the category of good grades that is $77.6 \%$. This means students are able to make a medium with good quality and high creativity. Meanwhile, cognitive aspects also have a satisfying point of $76 \%$ which means students have the ability to understand the scope of International Relations, the international aspects of events and events that occur around us, and the students' knowledge of the basic concepts in International Relations. The elements in affective aspects related to self-confidence, the ability to accept, respond to, and appreciate the opinions/suggestions/criticisms/questions of others and the ability to work in teams are also displayed very well by students through audiovisual media as well as when presentations and 
discussions in class. This section is the lowest rating of all aspects which is $70.8 \%$. Although students already have good self-confidence, but due to lack of experience the ability to accept, respond to, and appreciate the opinions/suggestions/criticisms/questions of others tends to be immature and emotional. Finally, the psychomotor element is also one of the aspects that has a lower rating compared to the media and cognitive aspects, which is $71.2 \%$. In this section students generally answer questions without supporting data. In addition, the initiative in answering questions tends to be done by the same person, meaning that spontaneity for all groups answering questions is still parenthetical and still relies on a few people. It can be concluded that the application of learning methods and assessment methods are generally effective in stimulating the cognitive, affective and psychomotor elements of students

\section{Conclusion}

The application of learning methods by developing vlogs in the Introduction to International Relations is considered quite effective compared to the methods previously applied to the same subject. Through the application of performance assessment methods, assessment of student learning outcomes can include hard skills and soft skills. At the end of the lecture, the success of the learning process of this course can be seen as satisfying and shows an improvement when compared with the previous assessment; as much as $62.06 \%$ of students received A and A-grades, while the number of students who do not pass this course is very small, which is $4,58 \%$.

\section{Reference}

[1] Chun, Christine dkk. 2017. Teaching Generation Z at the University of Hawaii, Hawaii: The IAFOR International Conference on Education

[2] DIKTI. 2005. Alternative Assesment. Depdiknas. Jakarta

[3] DIKTI, 2005, Aplikasi Penelitian Tindakan Kelas, Dirjen Dikti, Depdiknas

[4] DIKTI. 2012. Panduan Pengembangan dan Penyusunan Kurikulum pendidikan Tinggi Pendekatan Kurikulum Berbasis Kompetensi (KBK), dan Pendidikan Berbasis Capaian (PBC). Kemendikbud. Jakarta

[5] Kurniawati, Dyah Estu. 2012. Pendekatan Intermestik dalam Proses Perubahan Kebijakan: Sebuah Review Metodologis Jurnal Studi Hubungan Internasional Universitas Muhammadiyah Malang. Vol 2, No 2 (2012): Desember

[6] Kusumaningrum, Demeiati N dan Kurniawati, Dyah Estu. 2016. Intermestik sebagai Pendekatan Studi Hubungan Internasional: Pengantar dan Contoh Penelitian. Yogyakarta: LeutikaPrio

[7] LP3M. 2014. Panduan Praktis Pelaksanaan Student- Centered Learning (SCL): Meningkatkan Interaksi Mahasiswa dan Dosen dalam Pembelajaran. Padang: Universitas Andalas

[8] Pusat Pengembangan Sistem Pembelajaran. 2007. Panduan Evaluasi Pembelajaran, Surakarta: Lembaga Pengembangan Pendidikan Universitas Sebelas Maret

[9] Suganda, Tarkus. 2018. Pengelolaan Pembelajaran Generasi Z. Makalah Seminar Pembelajaran Bagi Generasi Z di Stipar Yapari, Bandung

[10] Thiagarajan, Sivasailam dkk. 1974. Instructional Development for Training Teachers of Exceptional Children: A Sourcebook. US: Indiana University

[11] Wibawanto, Hari. Generasi Z dan Pembelajaran di Pendidikan Tinggi. Bandung: UPT elearning ITB diakses dari

[12] https://event.elearning.itb.ac.id/assets/download/materi3.pdf (19 Februari 2019) 